\title{
KIF23 Gene
}

National Cancer Institute

\section{Source}

National Cancer Institute. KIF23 Gene. NCI Thesaurus. Code C104161.

This gene is involved in cytokinesis and microtubule movement. 